\title{
Discovering Antioxidant Molecules in the Archaea Domain: Peroxiredoxin Bcp1 from Sulfolobus solfataricus Protects H9c2 Cardiomyoblasts from Oxidative Stress
}

\author{
Carmen Sarcinelli, Gabriella Fiorentino, Elio Pizzo, \\ Simonetta Bartolucci, and Danila Limauro \\ Dipartimento di Biologia, Università di Napoli “Federico II", Via Cinthia, 80126 Naples, Italy \\ Correspondence should be addressed to Danila Limauro; limauro@unina.it
}

Received 23 March 2016; Revised 29 June 2016; Accepted 31 July 2016

Academic Editor: Nils K. Birkeland

Copyright ( 2016 Carmen Sarcinelli et al. This is an open access article distributed under the Creative Commons Attribution License, which permits unrestricted use, distribution, and reproduction in any medium, provided the original work is properly cited.

\begin{abstract}
Peroxiredoxins (Prxs) are ubiquitous thiol peroxidases that are involved in the reduction of peroxides. It has been reported that prokaryotic Prxs generally show greater structural robustness than their eukaryotic counterparts, making them less prone to inactivation by overoxidation. This difference has inspired the search for new antioxidants from prokaryotic sources that can be used as possible therapeutic biodrugs. Bacterioferritin comigratory proteins (Bcps) of the hyperthermophilic archaeon Sulfolobus solfataricus that belong to the Prx family have recently been characterized. One of these proteins, Bcpl, was chosen to determine its antioxidant effects in $\mathrm{H} 9 \mathrm{c} 2$ rat cardiomyoblast cells. Bcpl activity was measured in vitro under physiological temperature and $\mathrm{pH}$ conditions that are typical of mammalian cells; the yeast thioredoxin reductase ( $y$ TrxR)/thioredoxin $(y \operatorname{Trx})$ reducing system was used to evaluate enzyme activity. A TAT-Bcpl fusion protein was constructed to allow its internalization and verify the effect of $\mathrm{Bcp} 1$ on $\mathrm{H} 9 \mathrm{c} 2$ rat cardiomyoblasts subjected to oxidative stress. The results reveal that TAT-Bcpl is not cytotoxic and inhibits $\mathrm{H}_{2} \mathrm{O}_{2}$-induced apoptosis in $\mathrm{H} 9 \mathrm{c} 2$ cells by reducing the $\mathrm{H}_{2} \mathrm{O}_{2}$ content inside these cells.
\end{abstract}

\section{Introduction}

Reactive oxygen species (ROS), notably, superoxide $\left(\mathrm{O}_{2}{ }^{--}\right)$, the hydroxyl radical $\left(\mathrm{HO}^{\circ}\right)$, and hydrogen peroxide $\left(\mathrm{H}_{2} \mathrm{O}_{2}\right)$, are potent oxidants that are generated during aerobic metabolism and in response to external factors. At high concentrations, ROS can damage all major classes of biological macromolecules, leading to protein oxidation, lipid peroxidation, DNA base modifications, and strand breaks. In addition, $\mathrm{H}_{2} \mathrm{O}_{2}$ plays a key role in cellular metabolism because it functions as a signalling molecule that regulates cell growth, cell adhesion, cell differentiation, and apoptosis. For these reasons, the ROS concentrations must be strictly controlled. However, the regulation of the ROS concentrations within cells is not clearly understood [1].

Living organisms have evolved different antioxidant defence systems to protect themselves against ROS toxicity. Among the antioxidant enzymes, superoxide dismutase
(SOD) is involved in the dismutation reaction of $\mathrm{O}_{2}{ }^{--}$in $\mathrm{H}_{2} \mathrm{O}_{2}$ that in turn is converted to $\mathrm{H}_{2} \mathrm{O}$ by an array of enzymes, such as catalase, glutathione peroxidase (GPx), and peroxiredoxin (Prx). Recently, attention has been given to Prxs, which are ubiquitous thiol peroxidases in archaea and eukaryotes, including humans. All Prxs share a common structure characterized by the thioredoxin (Trx) fold [2]. Prxs are typically classified as either 1-Cys Prxs or 2-Cys Prxs, depending upon the cysteine residues involved in catalysis. In 2-Cys Prxs, the first cysteine is located at the $\mathrm{N}$-terminus and it is known as peroxidatic cysteine $\left(C_{p}\right)$, whereas the second cysteine is called the resolving cysteine $\left(C_{R}\right)$. The $C_{R}$ is situated at the $\mathrm{C}$-terminus or in different central positions downstream of $\mathrm{C}_{P}[3,4] . \mathrm{H}_{2} \mathrm{O}_{2}$ oxidizes $\mathrm{C}_{\mathrm{P}}$ to sulfenic acid $\left(\mathrm{C}_{\mathrm{P}}-\mathrm{SOH}\right)$, which in turn condenses with $\mathrm{C}_{\mathrm{R}}$ to form a disulfide bond. A disulfide reducing system, generally composed of thioredoxin reductase (TrxR)/thioredoxin (Trx), is coupled to Prx for recycling [5]. In some Prxs, called sensitive Prxs, 
$\mathrm{H}_{2} \mathrm{O}_{2}$ can further oxidize $\mathrm{C}_{\mathrm{P}}-\mathrm{SOH}$ to its inactive forms, the sulfinic $\left(\mathrm{C}_{\mathrm{P}}-\mathrm{SO}_{2} \mathrm{H}\right)$ or sulfonic $\left(\mathrm{C}_{\mathrm{P}}-\mathrm{SO}_{3} \mathrm{H}\right)$ acids, thereby preventing disulfide bond formation and inactivating the enzyme. The reason for this sensitivity is due to specific structural motifs. Specifically, a "GGLG" sequence and a YF C-terminal extension stiffen and stabilize the fully folded (FF) active site, making the enzyme more susceptible to overoxidation [6-8]. For this reason, eukaryotic Prxs are termed sensitive in contrast to the large majority of prokaryotic Prxs, which are considered robust because they lack these motifs [9]. This structural feature acquired during the evolution endows sensitive Prxs with additional functionality beyond basic antioxidant activity, including the ability to regulate peroxide signalling in eukaryotic cells [10].

An array of bacterioferritin comigratory proteins (Bcps) belonging to Prx family, named Bcp1, Bcp2, Bcp3, and Bcp4, have been recently characterized from the hyperthermophilic archaeon Sulfolobus solfataricus [2, 11-13]. Archaeal Bcp1 was expressed in E. coli and characterized [4]. It is reported that $\mathrm{Bcpl}$ regenerates through an unusual coupling mechanism. Specifically, a reduction mediated by the interaction of SsTrxR (Sso2416) and Protein Disulfide Oxidoreductase (SsPDO) (Sso0192) [14-16] replaces the standard Trx. Functional studies reveal that $\mathrm{Bcpl}$ performs the catalytic reaction using an atypical 2-Cys mechanism, in which $\mathrm{C}_{\mathrm{P}} 45$ forms an intramolecular disulfide bond with $\mathrm{C}_{\mathrm{R}} 50$. The $\mathrm{X}$-ray structure of the C45S/C50S double mutant, which represents the fully reduced enzyme state, was determined to a resolution of $2.15 \AA$ and showed a Trx fold that was similar to other Prxs [4].

This paper shows that archaeal Prx can function as an antioxidant in eukaryotic cells. Specifically, our data show $\mathrm{Bcpl}$ peroxidase activity under $\mathrm{pH}$ and temperature conditions that are typical of mammalian cells. Furthermore, we show that the archaeal Prx is active, although eukaryotic recycling system (different from that of Sulfolobus) is used [14]. A fusion protein consisting of HIV Transactivating Transduction (TAT) peptide [17] and Bcpl was constructed to facilitate uptake into $\mathrm{H} 9 \mathrm{c} 2$ cells. Its possible cytotoxic effects and ability to decrease the $\mathrm{H}_{2} \mathrm{O}_{2}$ levels inside the cells were also evaluated. Our results indicate that in an in vitro cellular system (i.e., H9c2 rat cardiomyoblasts), the archaeal enzyme can (1) function as an antioxidant to reduce the endogenous peroxide levels and (2) decrease cellular apoptosis following $\mathrm{H}_{2} \mathrm{O}_{2}$-induced stress.

\section{Materials and Methods}

\subsection{Expression and Purification of Recombinant Proteins in E. coli}

2.1.1. Bcp1 from S. solfataricus. Escherichia coli BL21-CodonPlus (DE3)RIL/pETBcp1 [12] was grown to $\mathrm{OD}_{600 \mathrm{~nm}}$ of 0.8 in Luria-Bertani (LB) medium supplemented with kanamycin $\left(10 \mu \mathrm{g} \mathrm{mL}^{-1}\right)$ and chloramphenicol $\left(34 \mu \mathrm{g} \mathrm{mL}^{-1}\right)$ at $37^{\circ} \mathrm{C}$. $\mathrm{Bcpl}$ expression was induced with $1 \mathrm{mM}$ isopropyl- $\beta$-Dthiogalactoside (IPTG) (Inalco) for $6 \mathrm{~h}$ at $37^{\circ} \mathrm{C}$. E. coli cells containing the recombinant protein were harvested by centrifugation, and the pellet from a $1 \mathrm{~L}$ culture was suspended in $20 \mathrm{~mL}$ of ice-cold $20 \mathrm{mM}$ Tris- $\mathrm{HCl}, \mathrm{pH} \mathrm{8.0,}$ containing a complete EDTA-free protease inhibitor cocktail (Roche, IN, USA). The protein was purified using a previously described method [11].

\subsubsection{Thioredoxin ( $y \operatorname{Tr} x)$ and Thioredoxin Reductase ( $y \operatorname{Tr} x R)$} from Yeast. E. coli BL21-CodonPlus (DE3)RIL was transformed with pET17yTrx or pET17yTrxR [18] (both generously provided by Sang Won Kang, University of Seoul, Korea) and cultured in $1 \mathrm{~L}$ of $\mathrm{LB}$ medium supplemented with ampicillin $\left(100 \mu \mathrm{g} \mathrm{mL}^{-1}\right)$ and chloramphenicol $\left(34 \mu \mathrm{g} \mathrm{mL}^{-1}\right)$ at $37^{\circ} \mathrm{C}$. The expression of both $y \operatorname{Trx}$ and $y \operatorname{TrxR}$ was induced with $0.5 \mathrm{mM}$ IPTG for $16 \mathrm{~h}$ at $37^{\circ} \mathrm{C}$ to an $\mathrm{OD}_{600 \mathrm{~nm}}$ of 0.8 . The $E$. coli cells were harvested by centrifugation and each pellet was suspended in $20 \mathrm{~mL}$ of ice-cold $20 \mathrm{mM}$ Tris- $\mathrm{HCl}$, pH $7.5,10 \mathrm{mM} \mathrm{NaCl}, 5 \mathrm{mM}$ DTT, $1 \mathrm{mM}$ EDTA, and a complete EDTA-free protease inhibitor cocktail and disrupted by sonication with $5 \mathrm{~min}$ pulses at $20 \mathrm{~Hz}\left(30^{\prime \prime}\right.$ on and $30^{\prime \prime}$ off). The soluble fractions were obtained after ultracentrifugation at $160,000 \times \mathrm{g}$ for $30 \mathrm{~min}$ at $4^{\circ} \mathrm{C}$.

The cell extract was heated at $75^{\circ} \mathrm{C}$ for $30 \mathrm{~min}$, centrifuged at $15,000 \times \mathrm{g}$ at $4^{\circ} \mathrm{C}$ for $30 \mathrm{~min}$, and then concentrated (Amicon, Millipore Corp., Bedford, MA, USA) to purify $y \operatorname{Trx}$. The sample was loaded on a Superdex S-75 column $(30 \mathrm{~cm} \times 1 \mathrm{~cm}$, $25 \mathrm{~mL}$ ) that had been equilibrated with $50 \mathrm{mM}$ Tris- $\mathrm{HCl}, \mathrm{pH}$ 7.5 , and $0.2 \mathrm{M} \mathrm{KCl}$ and was connected to an AKTA system (GE Healthcare). The elution was performed at a flow rate of $0.4 \mathrm{~mL} \mathrm{~min}^{-1}$.

The sample was loaded onto a Hi-Trap DEAE FF column $(7 \times 25 \mathrm{~mm}, 1 \mathrm{~mL})$ in $20 \mathrm{mM}$ Tris- $\mathrm{HCl}, \mathrm{pH} 7.5$, and $1 \mathrm{mM}$ EDTA connected to AKTA system (GE Healthcare) to purify $y \operatorname{TrxR}$. The proteins were eluted with a linear gradient of $0-$ $0.5 \mathrm{M} \mathrm{NaCl}$ in $30 \mathrm{~min}$ at a flow rate of $0.5 \mathrm{~mL} \mathrm{~min}^{-1}$.

For both proteins, the fractions were pooled, analysed by SDS-PAGE, and extensively dialysed against $20 \mathrm{mM}$ Tris$\mathrm{HCl}, \mathrm{pH} 7.0$.

\subsection{Enzymatic Activities}

2.2.1. $y \operatorname{Trx}$ and $y \operatorname{Tr} x R$ Activity Assays. $y \operatorname{Trx}$ activity was detected using the insulin precipitation assay [19], in a reaction mixture containing $0.1 \mathrm{M}$ sodium phosphate $\mathrm{pH}$ 7.0, $2 \mathrm{mM}$ EDTA, $1 \mathrm{mg} \mathrm{mL}^{-1}$ insulin, $1 \mathrm{mM}$ DTT, and $5 \mu \mathrm{M}$ yTrx. The increase in the absorbance due to the precipitation of the insulin B chain was monitored at $650 \mathrm{~nm}$ in a Varian Cary 50 Bio UV-Vis spectrophotometer.

$y \operatorname{TrxR}$ activity was evaluated using the 5,5'-dithiobis(2nitrobenzoic acid) (DTNB) reduction method [20]. The formation of the 2-nitro-5-thiobenzoate product was monitored spectrophotometrically by the increase at $A_{412 \mathrm{~nm}}$ at $30^{\circ} \mathrm{C}$. The reaction mixture contained $0.1 \mathrm{M}$ potassium phosphate, $\mathrm{pH}$ 7.0, $2 \mathrm{mM}$ EDTA, $0.2 \mathrm{mM}$ NADPH, $0.05 \mathrm{mM}$ FAD, $0.5 \mathrm{mM}$ DTNB, and $0.2 \mu \mathrm{M}$ yTrxR.

2.2.2. Bcpl Activity Assays. Bcpl peroxidase activity was tested in an assay using DTT [11]. The reaction mixture contained $0.1 \mathrm{M}$ Hepes, pH 7.0, $10 \mathrm{mM}$ DTT, $0.1 \mathrm{mM} \mathrm{H}_{2} \mathrm{O}_{2}$, and $10 \mu \mathrm{M}$ 
Bcp1. After incubation for $5 \mathrm{~min}$ at $37^{\circ} \mathrm{C}$, the reaction was stopped adding a trichloroacetic acid solution $(10 \% \mathrm{w} / \mathrm{v})$. The amount of $\mathrm{H}_{2} \mathrm{O}_{2}$ remaining was detected by measuring the $A_{490 \mathrm{~nm}}$ of the purple-coloured ferrothiocyanate complex that developed after the addition of $0.2 \mathrm{~mL}$ of $10 \mathrm{mM}$ $\mathrm{Fe}\left(\mathrm{NH}_{4}\right)_{2}\left(\mathrm{SO}_{4}\right)_{2}$ and $0.1 \mathrm{~mL}$ of $2.5 \mathrm{M} \mathrm{KSCN}$.

The effect of $\mathrm{pH}$ on $\mathrm{Bcpl}$ activity was analysed using $0.1 \mathrm{M}$ citrate phosphate $(\mathrm{pH} 5.5-6.5)$ and $0.1 \mathrm{M}$ Hepes $(\mathrm{pH}$ 7.0-7.5) buffers and the assay conditions reported above. The $\mathrm{pH}$ stability of Bcpl was also evaluated after the enzyme was incubated in the buffers ( $\mathrm{pH} \mathrm{5.5-7.0)} \mathrm{for} 30 \mathrm{~min}, 1 \mathrm{~h}, 2 \mathrm{~h}, 4 \mathrm{~h}$, and $16 \mathrm{~h}$, and the residual peroxidase activity was determined under standard conditions.

The peroxidase activity was also evaluated using NADPH/yTrxR/yTrx as the electron donor system to reduce Bcpl. The assay mixture contained $50 \mathrm{mM}$ Hepes, $\mathrm{pH}$ 7.0, $1 \mathrm{mM}$ EDTA, $0.2 \mathrm{mM}$ NADPH, 5-100 $\mu \mathrm{M}$ yTrx, $0.1 \mu \mathrm{M}$ yTrxR, and $3.5 \mu \mathrm{M}$ Bcpl. After preincubation at $30^{\circ} \mathrm{C}$ for $2 \mathrm{~min}$, the reaction was started by adding $0.2 \mathrm{mM} \mathrm{H}_{2} \mathrm{O}_{2}$. The NADPH oxidation was monitored spectrophotometrically at $340 \mathrm{~nm}$.

2.3. TAT-Bcp1: Cloning, Expression, and Purification. The bcp1 coding sequence was isolated from the $\mathrm{pET} 30 \mathrm{Bcp} 1$ vector [12] after digestion with the NdeI and XhoI restriction endonucleases. The $b c p 1$ fragment was purified by agarose gel electrophoresis using the QIAquick Gel Extraction Kit (Qiagen, Milano, Italy) and cloned into the pTAT2.2 expression vector (Addgene, Cambridge, USA). E. coli BL21CodonPlus (DE3)RIL competent cells were transformed with the obtained vector, pTAT2.2-Bcpl, and selected on LB agar plates with kanamycin $\left(10 \mu \mathrm{g} \mathrm{mL}^{-1}\right)$ and chloramphenicol $\left(34 \mu \mathrm{g} \mathrm{mL}^{-1}\right)$. The selected colony was cultured in LB medium with the same antibiotics at $37^{\circ} \mathrm{C}$. The cells were grown up to an $\mathrm{OD}_{600 \mathrm{~nm}}$ of 0.8 and the expression of TAT-Bcp1 was induced with $1 \mathrm{mM}$ IPTG for $3 \mathrm{~h}$ at $37^{\circ} \mathrm{C}$. TAT-Bcpl was purified using the same conditions described for Bcpl. Peroxidase activity was evaluated using the DTT assay at $37^{\circ} \mathrm{C}$, as reported for $\mathrm{Bcp} 1$.

2.4. Cell Culture and Treatment. H9c2 cells (Rat Embryonic Myocardium Cells, CRL-1446) were purchased from the American Type Culture Collection (ATCC) and grown in Dulbecco's Modified Eagle Medium (DMEM) supplemented with $10 \%$ foetal bovine serum (FBS), $4 \mathrm{mM}$ L-glutamine, a $1 \% \mathrm{v} / \mathrm{v}$ penicillin/streptomycin solution $\left(100 \mathrm{U} \mathrm{mL}^{-1}\right)$, and $1 \mathrm{mM}$ sodium pyruvate (Euroclone, Milano, Italy) at $37^{\circ} \mathrm{C}$ in a $5 \% \mathrm{CO}_{2}$ incubator. A freshly prepared $\mathrm{H}_{2} \mathrm{O}_{2}$ (Sigma-Aldrich, Milano, Italy) stock aqueous solution was added to the cells at a final concentration of $0.3 \mathrm{mM}$ and incubated for $1 \mathrm{~h}$ or $3 \mathrm{~h}$ to induce oxidative stress.

2.5. Internalization of TAT-Bcp1 in H9c2 Cells. H9c2 cells were seeded in 6 -well plates at a density of $2 \times 10^{5}$ cells/well in $2 \mathrm{~mL}$ of medium, and then TAT-Bcpl $(0.5-10 \mu \mathrm{M})$ was added to the cells and incubated for different times $(1 \mathrm{~h}, 4 \mathrm{~h}$, $16 \mathrm{~h}$, and $24 \mathrm{~h})$. As a control, the cells were incubated with buffer diluted in medium. The cells were then detached with
trypsin-EDTA, harvested by centrifugation, and washed with PBS. The cells were lysed on ice for $20 \mathrm{~min}$ in $0.5 \%$ Triton $\mathrm{X}-100$ in PBS containing a complete EDTA-free protease inhibitor cocktail. After centrifugation at $1,500 \times \mathrm{g}$ for $10 \mathrm{~min}$ at $4^{\circ} \mathrm{C}$, the supernatant representing the cytoplasmic fraction was collected and quantified by the Bradford method [21] using Bio-Rad Protein Assay Reagent (Bio-Rad, Germany). Fifty micrograms of cytoplasmic proteins was separated by SDS-PAGE on a gel containing $15 \%$ polyacrylamide and then examined by western blot analysis using a horseradish peroxidase- (HRP-) conjugated anti-5X His tag antibody (mAb) (Qiagen) diluted 1:2,000 in blocking buffer. Chemiluminescent detection was performed according to the manufacturer's recommendations (Immobilon Western Chemiluminescent HRP Substrate, Millipore, MA, USA) using the Chemidoc system (Bio-Rad). The quantitative analysis was performed using Quantity One software.

2.6. Cell Viability Assay. Cell viability was evaluated using the 3-(4,5-dimethylthiazol-2-yl)-2,5-diphenyltetrazolium bromide (MTT) assay [22]. H9c2 cells were seeded in 96well plates at a density of $3.5 \times 10^{3}$ cells/well in $0.1 \mathrm{~mL}$ of DMEM. After $24 \mathrm{~h}$, the cells were incubated with $10 \mu \mathrm{M}$ TAT-Bcpl for different times $(1 \mathrm{~h}, 4 \mathrm{~h}, 16 \mathrm{~h}, 24 \mathrm{~h}, 48 \mathrm{~h}$, and $72 \mathrm{~h})$. As a control, the cells were incubated with buffer diluted in medium. The MTT solution (Sigma-Aldrich, Milano, Italy) was added at $0.5 \mathrm{mg} \mathrm{mL}^{-1}$ in DMEM without phenol red $(0.1 \mathrm{~mL} /$ well $)$. After a $4 \mathrm{~h}$ incubation at $37^{\circ} \mathrm{C}$, the formazan salts were solubilized in $0.04 \mathrm{M} \mathrm{HCl}$ in anhydrous isopropanol and cell viability was evaluated by measuring the $A_{570 \mathrm{~nm}}$ using an automatic plate reader spectrophotometer (VICTOR3 $^{\text {TM }}$ Multilabel Counter, Perkin Elmer, Shelton, CA, USA). Cell survival was expressed as the means of the percentage values compared to the control. Each sample was analysed in triplicate and the assay has been repeated at least three times.

2.7. Measurement of the $\mathrm{H}_{2} \mathrm{O}_{2}$ Content. The $\mathrm{H}_{2} \mathrm{O}_{2}$ levels were determined using a Fluorescent Peroxide Sensor (MAK164 Sigma-Aldrich), which generates a fluorescent product proportional to the $\mathrm{H}_{2} \mathrm{O}_{2}$ content following a reaction with $\mathrm{H}_{2} \mathrm{O}_{2}$.

The intracellular $\mathrm{H}_{2} \mathrm{O}_{2}$ levels were measured under (1) physiological and (2) stressed conditions.

(1) H9c2 cells were pretreated or with or without increasing concentrations of TAT-Bcpl $(1-20 \mu \mathrm{M})$ for $60 \mathrm{~min}$ at $37^{\circ} \mathrm{C}$. Next, the cells were washed twice in PBS and lysed as reported above. Then, the samples were incubated with the Fluorescent Peroxide Sensor diluted in working solution according to the manufacturer's instructions and incubated for $30 \mathrm{~min}$ at $37^{\circ} \mathrm{C}$. The fluorescence intensity was measured using a multimode reader synergy HT calibrated for excitation at $490 \mathrm{~nm}$ and emission at $525 \mathrm{~nm}$.

(2) $\mathrm{H} 9 \mathrm{c} 2$ cells were pretreated with TAT-Bcp1 $(10 \mu \mathrm{M}$ for $16 \mathrm{~h}$ ) and then stressed with $0.3 \mathrm{mM} \mathrm{H}_{2} \mathrm{O}_{2}$ for 30 or $60 \mathrm{~min}$ at $37^{\circ} \mathrm{C}$. The cells were then washed and lysed, 
and finally the $\mathrm{H}_{2} \mathrm{O}_{2}$ levels were measured using the fluorescence assay described above. Every experiment included four replicates.

2.8. Cell Apoptosis. H9c2 cells were seeded in 6-well plates at a density of $1.5 \times 10^{5}$ cells/well in $2 \mathrm{~mL}$ of DMEM and grown to nearly $70 \%$ confluence. The cells were then incubated with $10 \mu \mathrm{M}$ TAT-Bcp1 for different times ( $1 \mathrm{~h}, 4 \mathrm{~h}, 16 \mathrm{~h}$, and $24 \mathrm{~h}$ ) before treatment with $\mathrm{H}_{2} \mathrm{O}_{2}(0.3 \mathrm{mM}$ for 1 and $3 \mathrm{~h})$.

2.9. EB and AO Staining Assay. Apoptotic cells were detected by ethidium bromide (EB) and Acridine Orange (AO) staining of the nuclei [23]. AO permeates all cells and stains the nuclei green, whereas EB is only incorporated in apoptotic cells, staining the nuclei red.

The cells were detached with trypsin-EDTA, washed with ice-cold PBS, resuspended in $50 \mu \mathrm{L}$ of PBS containing a $5 \mu \mathrm{g} \mathrm{mL}^{-1} \mathrm{~EB} / \mathrm{AO}$ dye mixture, and incubated at $37^{\circ} \mathrm{C}$ for $20 \mathrm{~min}$. The stained cells were visualized under a fluorescence microscope (Nikon Eclipse E-100). Images were taken at 100x magnification. Both the apoptotic (red) and live (green) cells in each sample were counted in five microscopic fields.

2.10. PARP-1 Cleavage. Nuclear extracts were prepared by detaching the cells with trypsin-EDTA, incubating them on ice for $10 \mathrm{~min}$ in $10 \mathrm{mM}$ Hepes, $\mathrm{pH} 8.0$, containing $10 \mathrm{mM}$ $\mathrm{KCl}, 1.5 \mathrm{mM} \mathrm{MgCl}_{2}, 0.5 \mathrm{mM}$ DTT, and a complete EDTA-free protease inhibitor cocktail (Roche), lysing them by adding $0.1 \% \mathrm{NP}-40$, and centrifuging the lysates at $1,500 \times \mathrm{g}$ for $10 \mathrm{~min}$ at $4^{\circ} \mathrm{C}$. The pellet was dissolved in RIPA buffer $(50 \mathrm{mM}$ Tris- $\mathrm{HCl}, \mathrm{pH} 8.0,150 \mathrm{mM} \mathrm{NaCl}, 1 \% \mathrm{NP}-40,0.5 \%$ sodium deoxycholate, and $0.1 \%$ SDS) containing a protease inhibitor cocktail and incubated on ice for $30 \mathrm{~min}$. After centrifugation at $1,500 \times \mathrm{g}$ for $30 \mathrm{~min}$ at $4^{\circ} \mathrm{C}$, the nuclear protein concentration was measured using the Bradford method [21], and $30 \mu \mathrm{g}$ of the protein extracts was separated by $10 \%$ SDS-PAGE. Western blotting analysis was performed using the chemiluminescent method and the following antibodies: poly(ADP-ribose) polymerase-1 (PARP-1) mAb (C2-10, Santa Cruz, CA) diluted $1: 2,000$ in blocking buffer (5\% BSA in TBS buffer containing $0.1 \% \mathrm{v} / \mathrm{v}$ Tween 20 ) or the B23 mAb (SigmaAldrich, St. Louis, USA; $1: 2,000$ dilution) as loading control for the nuclear proteins. An HRP-conjugated goat anti-mouse IgG was used for detection (Pierce, Rockford, IL, USA).

2.11. Statistical Analysis. The data for the cell viability and cell apoptosis assays are presented as the means \pm SD of at least three repeats. Statistical analysis was performed using a two-tailed Student's $t$-test. A $p$ value $<0.05$ was defined as indicating a statistically significant difference.

\section{Results}

3.1. Sequence Alignment of Bcp1 with Prx Orthologues. The CLUSTAL multiple alignment of Bcpl versus human Prxs ( $h$ Prx 1 and $h \operatorname{Prx} 2$ ) [24], Prx (Dot5p) from Saccharomyces cerevisiae [25], and prokaryotic Prxs belonging to Vibrio vulnificus ( $V v \operatorname{Prx} 1$ and $V v \operatorname{Prx} 2)$ [9] was performed using
MUSCLE (3.8). As shown in Figure 1, Bcpl has the highest percent identity with Dot5p and $h$ PrxI of $35 \%$ and $33 \%$, respectively. The first similarly to Bcp1 is the atypical 2-Cys Prxs, and the two enzymes are characterized by a CxxxxxC motif, in which the two cysteine residues are the $C_{P}$ and $C_{R}$, respectively $[4,25]$, but it does not retain the sensitivity motifs to overoxidation (GGLG and YT at C-terminus). The latter, which belongs to the typical 2-Cys Prxs, has a similar percent identity but has the sensitivity motif that renders it susceptible to overoxidation. On the other hand, $V v \operatorname{Prx} 1$ and $V v \operatorname{Prx} 2$, which belong to the prokaryotic domain, show lower identity with Bcp1 (25\% and 27\%, resp.), and only the first presents the overoxidation motif. This analysis suggests that prokaryotic Bcpl could be a robust peroxiredoxin that also functions in all eukaryotic environments.

3.2. Bcp1 Peroxidase Activity. Bcpl was expressed in E. coli, purified [12], and the peroxidase activity was successively determined at $37^{\circ} \mathrm{C}$ and at different $\mathrm{pH}$ values using the DTT assay reported in the MM to detect $\mathrm{Bcpl}$ peroxidase activity under the typical temperature and $\mathrm{pH}$ conditions of eukaryotic cells. Our results showed that Bcp1 was able to remove $100 \%$ of $\mathrm{H}_{2} \mathrm{O}_{2}$ at $37^{\circ} \mathrm{C}$ (data not shown) and that the optimal peroxidase activity was achieved at $\mathrm{pH} 7.0$ (Figure 2(a)). In addition, $\mathrm{pH}$ stability was determined by incubating $\mathrm{Bcpl}$ at different $\mathrm{pH}$ values (5.5-7.0) for various times and then measuring $\mathrm{H}_{2} \mathrm{O}_{2}$ removal (Figure 2(b)). After $16 \mathrm{~h}$ incubation at $\mathrm{pH} 7.0, \mathrm{Bcp} 1$ retained $100 \%$ of its initial activity, while at $\mathrm{pH} 6.5,6.0$, and 5.5, the enzyme maintained $60 \%, 70 \%$, and $33 \%$ of its initial activity, respectively. At $\mathrm{pH}$ 5.5 , the relative $\mathrm{Bcp} 1$ activity decreased to $47 \%$ of the starting value after two hours of incubation.

It was previously described that Bcpl is coupled with an unusual redox system composed of SsTrxR with SsPDO for recycling [4]. We monitored the $\mathrm{Bcpl}$ peroxidase reaction using the yeast Trx system ( $y \operatorname{TrxR} / y \operatorname{Trx})$ and NADPH as an electron source to verify that Bcpl activity was supported by eukaryotic disulfide reductase system. This system was successfully used to measure the peroxidase activity of $h$ Prxl and $h \operatorname{Prx} 2[18,24]$. Therefore, we expressed and purified $y \operatorname{TrxR}$ and $y \operatorname{Trx}$ from $E$. coli and determined their reducing activities, as reported in the MM (data not shown). Initially, Bcpl peroxidase activity was determined by measuring the consumption of NADPH, which was revealed by a decrease in absorbance at $340 \mathrm{~nm}$ (Figure 3(a)); then, different concentrations of $y \operatorname{Trx}$ were used to determine the kinetic parameters (Figure 3(b)). Our results showed that Bcpl had a $K_{m}$ value of $54.9 \mu \mathrm{M}$ using this heterologous system.

3.3. Generation of a Pure TAT-Bcp1 Fusion Protein. Previous studies showed that when the HIV Transactivating Transduction (TAT) domain, a short basic polypeptide of 11 amino acids residues, was fused with a target protein it confers the ability to penetrate across the lipid bilayer of the cells due to the strong binding of the positively charged TAT domain to the negative charges on the cell surface [17].

We generated the TAT-Bcpl fusion protein by cloning bcp1 into pTAT2.2 vector to allow Bcp1 internalization into 


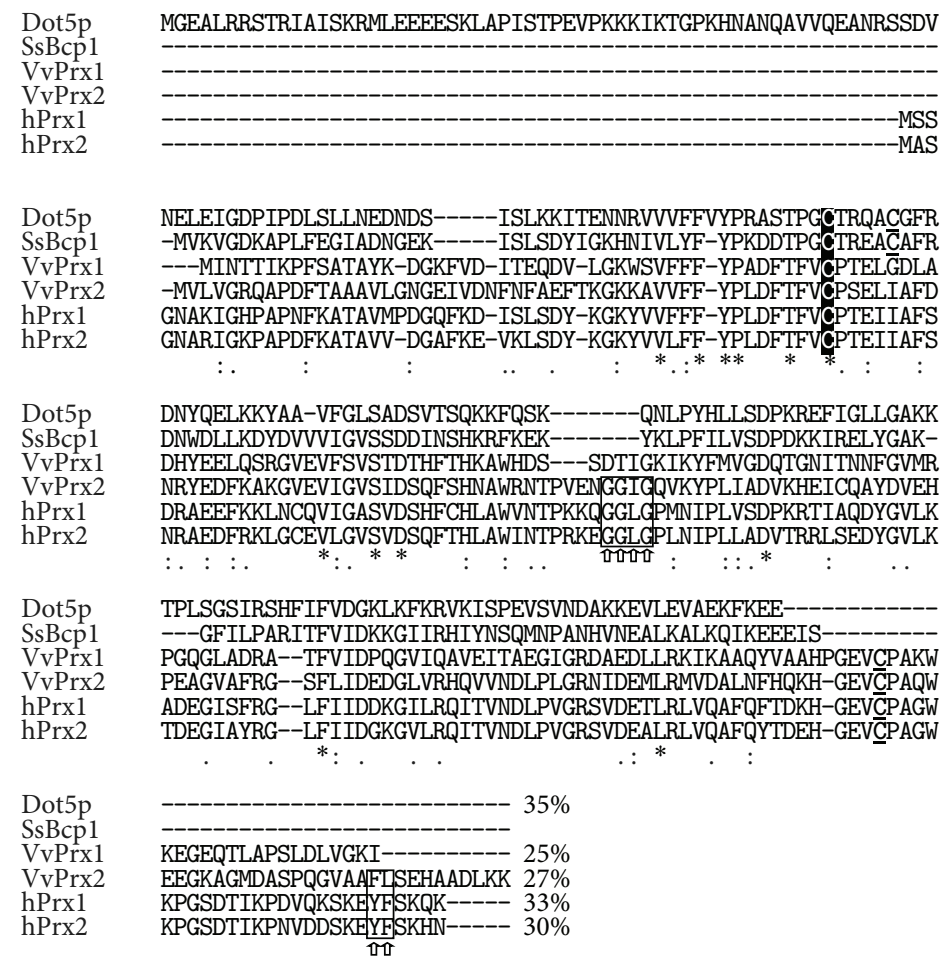

Figure 1: Alignment of $S s \mathrm{Bcp} 1$ with the Prx orthologues. The multiple sequence alignment of S. solfataricus Bcp1 (AAK42253), H. sapiens $h \operatorname{Prxl}$ (BAG70076) and $h \operatorname{Prx} 2$ (AAH39428), S. cerevisiae Dot5p (DAA08535), and V. vulnificus VvPrx1 (ADV88988) and VvPrx2 (ADV87477) was performed using the MUSCLE algorithm. Identical and similar amino acids are marked with asterisks and points, respectively. The peroxidatic cysteines are indicated in white and the resolving cysteines are underlined; the motifs for the sensitive Prxs are boxed and marked with arrows.

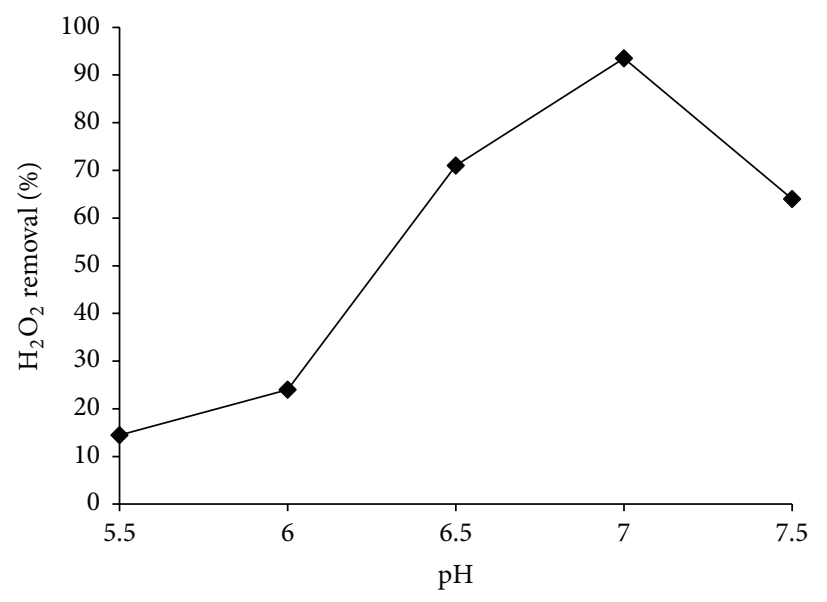

(a)

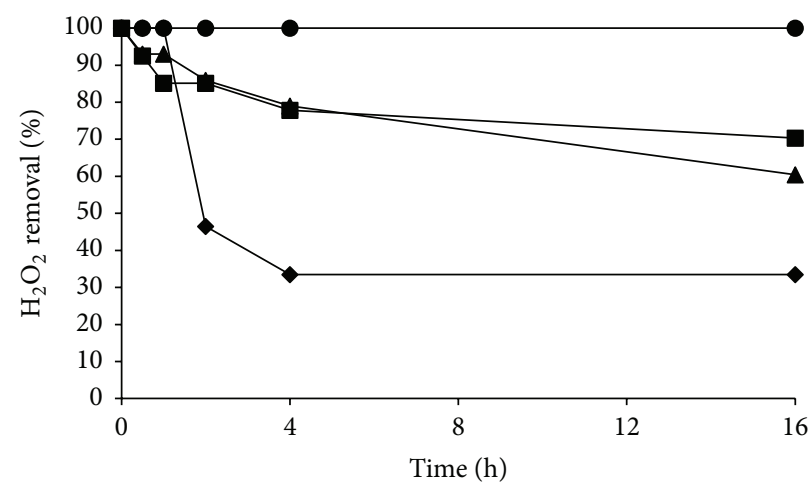

(b)

FIgURE 2: Analysis of the $\mathrm{pH}$ optimum and $\mathrm{pH}$ stability of $\mathrm{Bcpl} . \mathrm{H}_{2} \mathrm{O}_{2}$ removal was measured using the ferrothiocyanate method in the presence of DTT as the electron donor at $37^{\circ} \mathrm{C}$. (a) The optimum $\mathrm{pH}$ was measured in buffers within the range $\mathrm{pH}$ 5.5-7.5. (b) $\mathrm{pH}$ stability was determined at $37^{\circ} \mathrm{C}$ by incubating $\mathrm{Bcpl}$ in different buffers, pH $5.5(\diamond), \mathrm{pH} 6.0(\mathbf{\bullet})$, pH $6.5(\boldsymbol{\Delta})$, and pH $7.0(\bullet)$, for the following times: $30 \mathrm{~min}, 1 \mathrm{~h}, 2 \mathrm{~h}, 4 \mathrm{~h}$, and $16 \mathrm{~h}$.

the cell. The recombinant plasmid, pTAT2.2-Bcp1 (Figure S1A), was used to produce a soluble fusion protein with the TAT domain at the N-terminus and a His tag at the Cterminus. TAT-Bcpl was purified by heat-treatment followed by IMAC chromatography using the conditions described for Bcp1 [4]. The SDS-PAGE analysis (Figure S1B) revealed a single band of $\sim 19 \mathrm{kDa}$, which agreed with the predicted molecular weight of $20.229 \mathrm{kDa}$.

The purified enzyme was functionally characterized. The DTT assay was performed and the results revealed that, 


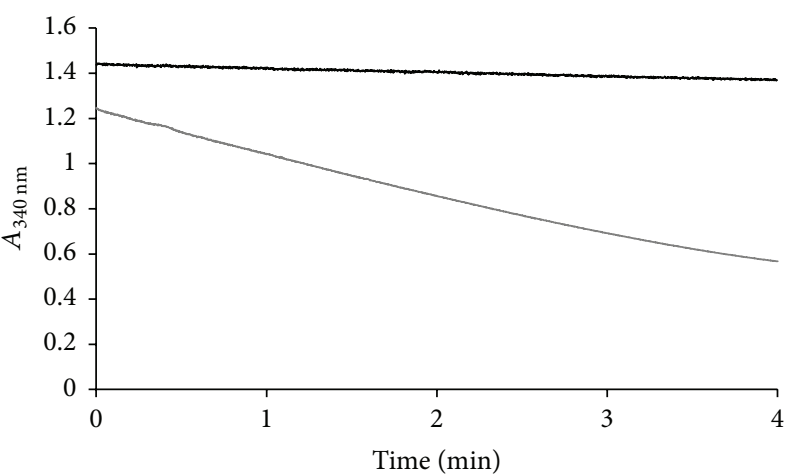

(a)

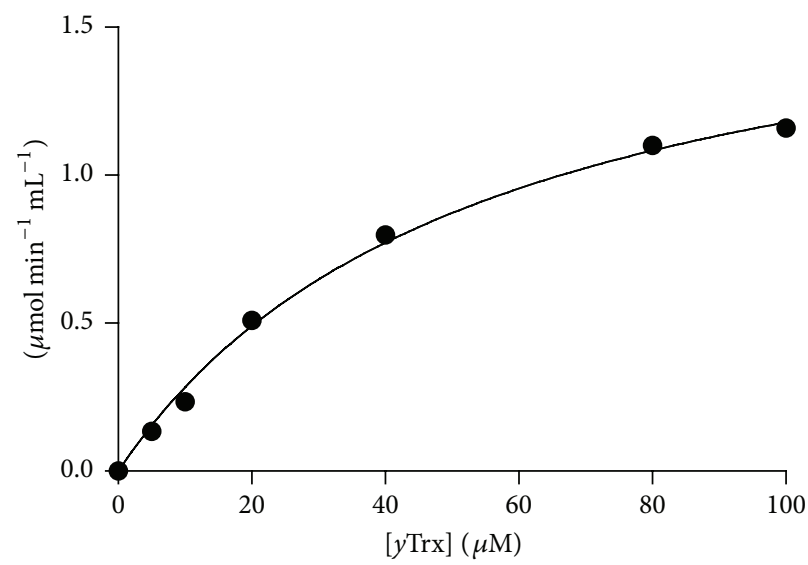

(b)

FIgURE 3: Bcpl peroxidase activity is dependent on $y \operatorname{TrxR} / y \operatorname{Trx}$. The activity was measured by the consumption of NADPH via a decrease in absorbance at $340 \mathrm{~nm}$. (a) Time course of NADPH oxidation: the peroxidase activity of $\mathrm{Bcpl}(3.5 \mu \mathrm{M})$ was measured at $30^{\circ} \mathrm{C}$ in presence of $y \operatorname{TrxR}(0.1 \mu \mathrm{M})$ and $y \operatorname{Trx}(0.1 \mathrm{mM})$. The reaction was started by adding $0.2 \mathrm{mM} \mathrm{H}_{2} \mathrm{O}_{2}$. (b) Michaelis-Menten plot of Bcp1 using $y \operatorname{Trx}$ as the substrate.

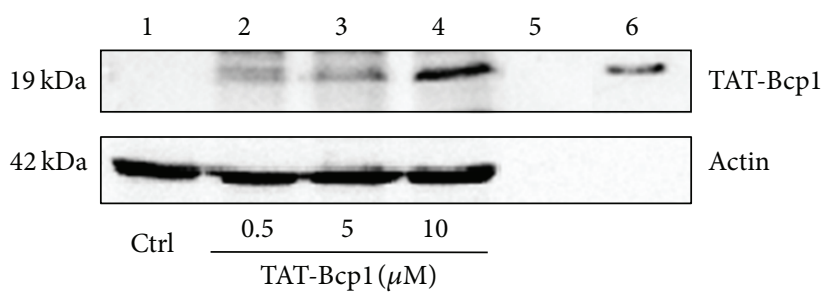

(a)

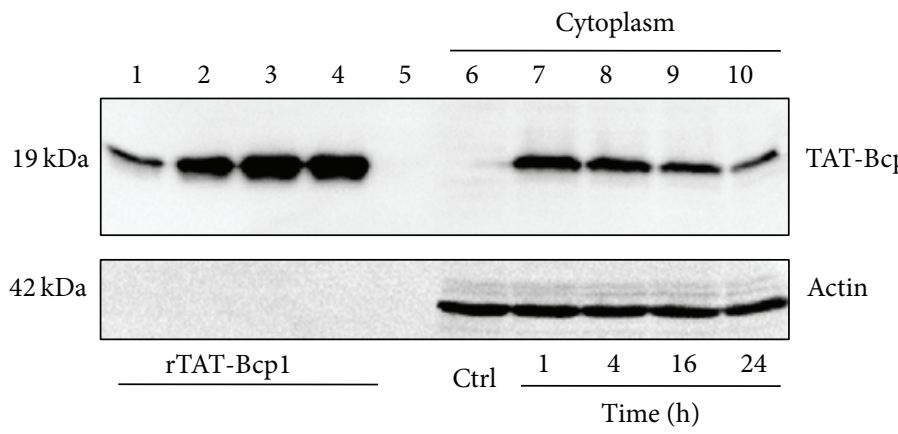

(b)

FIgURE 4: Transduction of TAT-Bcp1 in H9c2 cells. A western blot analysis of the cytoplasmic extracts was performed to detect TAT-Bcp1 in the H9c2 cells; the cytoplasmic proteins were analysed with a penta-His HRP-conjugated mAb. Actin was used as the cytoplasmic marker (lower panels). (a) H9c2 cells were cultured in growth medium (lane 1) and incubated with $0.5 \mu \mathrm{M}$ (lane 2), $5 \mu \mathrm{M}$ (lane 3), and 10 $\mu \mathrm{M}$ (lane 4) TAT-Bcpl for $1 \mathrm{~h}$. Purified TAT-Bcpl was loaded as reference (lane 6). (b) H9c2 cells were cultured in growth medium (lane 6) and incubated with TAT-Bcp1 $(10 \mu \mathrm{M})$ for $1 \mathrm{~h}$ (lane 7$), 4 \mathrm{~h}$ (lane 8), $16 \mathrm{~h}$ (lane 9), and $24 \mathrm{~h}$ (lane 10). Increasing amounts of purified TAT-Bcp1 were loaded to construct a calibration curve to determine the intracellular TAT-Bcpl levels: $25 \mathrm{ng}$ (lane 1), $50 \mathrm{ng}$ (lane 2), $75 \mathrm{ng}$ (lane 3), and 100 ng (lane 4).

similar to Bcpl, TAT-Bcp1 was able to reduce all of the $\mathrm{H}_{2} \mathrm{O}_{2}$ under the same $\mathrm{pH}$ and temperature conditions (data not shown).

3.4. TAT-Bcp1 Internalization into $H 9 c 2$ Cells. It is widely reported that $\mathrm{H}_{2} \mathrm{O}_{2}$ contributes to the initiation and the progression of cardiovascular diseases, including atherosclerosis [26]. We chose H9c2 rat cardiomyoblasts, nonmalignant cardiac-like cells that are commonly used to study the molecular response to oxidative damage [27], as a model system to evaluate the effects of TAT-Bcp1 on cells undergoing oxidative stress. First, we established the optimal conditions for TAT$\mathrm{Bcp} 1$ internalization. Therefore, we cultured the H9c2 cells and incubated them with different amounts $(0-10 \mu \mathrm{M})$ of the fusion protein for $1 \mathrm{~h}$. As shown in Figure 4(a), the western blot analysis of the cytoplasmic extracts showed that $10 \mu \mathrm{M}$ 


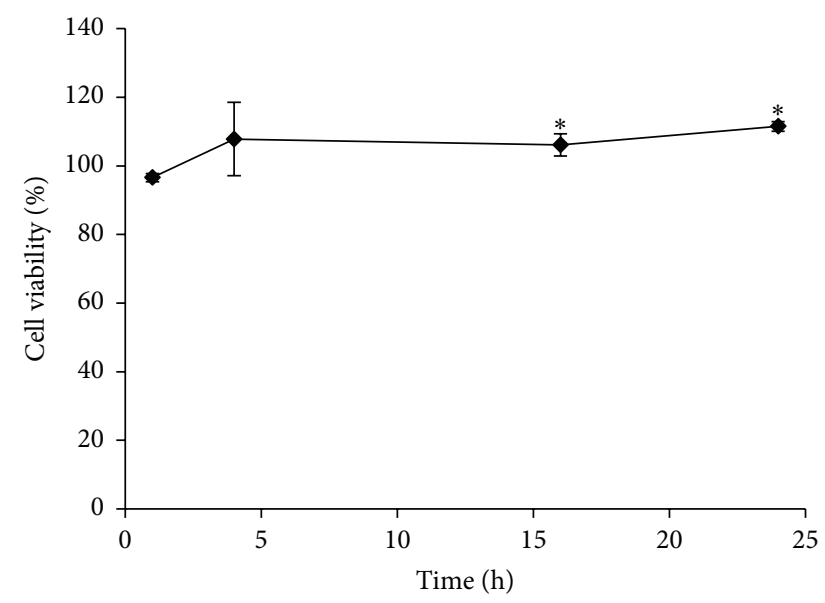

FIGURE 5: Effect of TAT-Bcp1 on H9c2 cell viability. Cell viability was determined using the MTT assay. The cells were cultured in normal growth medium and then treated with TAT-Bcp1 $(10 \mu \mathrm{M})$ for $1 \mathrm{~h}, 4 \mathrm{~h}$, $16 \mathrm{~h}$, and $24 \mathrm{~h}$. Cell viability was evaluated by measuring the $A_{570 \mathrm{~nm}}$; the data are expressed as the mean percentages \pm SD. compared to the control. ${ }^{*} p<0.001$; the results were derived from four replicates of a representative experiment.

TAT-Bcp1 was the optimal concentration for internalization into $\mathrm{H} 9 \mathrm{c} 2$ cells. Afterwards, TAT-Bcpl internalization was analysed at $1 \mathrm{~h}, 4 \mathrm{~h}, 16 \mathrm{~h}$, and $24 \mathrm{~h}$ (Figure $4(\mathrm{~b})$ ). The fusion protein was detected in the cells after $1 \mathrm{~h}$ (lane 7 , upper panel), whereas $16 \%, 49 \%$, and $69 \%$ decreases were observed after $4 \mathrm{~h}, 16 \mathrm{~h}$, and $24 \mathrm{~h}$, respectively (lanes 8-10, upper panel). This effect could be related to the common protein turnover mechanism because a constant amount of TATBcp1 was present in the supernatants at the different times (Figure S2, lanes 6-9 (see Supplementary Material available online at http://dx.doi.org/10.1155/2016/7424870)). No band was detected when buffer alone was diluted into the culture medium (Figure 4(a), lane 1, and Figure 4(b), lane 6, upper panels; Figure S2, lane 5). These data indicate that TAT-Bcp1 is optimally delivered into the cells at $10 \mu \mathrm{M}$ and is stable within $4 \mathrm{~h}$ after administration.

3.5. The Effect of TAT-Bcp1 on Cell Viability. The MTT assay was performed to evaluate whether TAT-Bcpl had any cytotoxic effect on the H9c2 cells. The cells were cultured in growth medium and treated with $10 \mu \mathrm{M}$ TAT-Bcpl for $1 \mathrm{~h}, 4 \mathrm{~h}$, $16 \mathrm{~h}$, and $24 \mathrm{~h}$ (Figure 5). After a $1 \mathrm{~h}$ incubation, cell growth was $96.6 \pm 1.2 \%$, whereas after $16 \mathrm{~h}$ and $24 \mathrm{~h}$, the cell survival was slightly but significantly higher than $100 \%(106.1 \pm 3.2$ and $111.5 \pm 1.4 \%$, resp.; $p$ value $<0.01$ ), showing that TAT$\mathrm{Bcp} 1$ was not cytotoxic to $\mathrm{H} 9 \mathrm{c} 2$ cells. The incubation was also extended to $72 \mathrm{~h}$ (Figure S3), and the results showed that $95 \%$ and $91 \%$ of the cells survived at $48 \mathrm{~h}$ and $72 \mathrm{~h}$, respectively, confirming the data described above.

3.6. TAT-Bcp1 Affects the $\mathrm{H}_{2} \mathrm{O}_{2}$ Concentrations in $\mathrm{H} 9 \mathrm{c} 2$ Cells under Physiological or Stressed Conditions. The endogenous $\mathrm{H}_{2} \mathrm{O}_{2}$ content was measured in lysates of $\mathrm{H} 9 \mathrm{c} 2$ cells that had been treated with increasing concentrations of TAT-Bcpl and

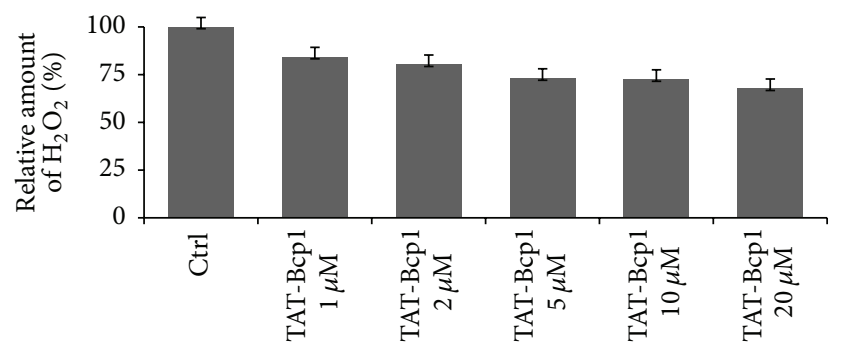

(a)

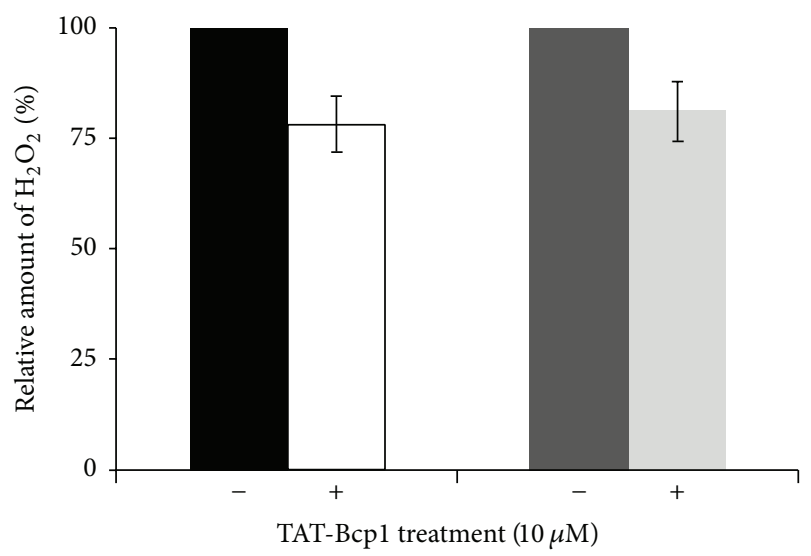

Stressed cells with $0.3 \mathrm{mM} \mathrm{H}_{2} \mathrm{O}_{2}$ for $30 \mathrm{~min}$

TAT-Bcpl pretreated cells stressed with $0.3 \mathrm{mM} \mathrm{H}_{2} \mathrm{O}_{2}$ for $30 \mathrm{~min}$ Stressed cells with $0.3 \mathrm{mM} \mathrm{H}_{2} \mathrm{O}_{2}$ for $60 \mathrm{~min}$

TAT-Bcp1 pretreated cells stressed with $0.3 \mathrm{mM} \mathrm{H}_{2} \mathrm{O}_{2}$ for $60 \mathrm{~min}$

(b)

FIgURE 6: Effect of TAT-Bcpl on $\mathrm{H}_{2} \mathrm{O}_{2}$ levels in H9c2 cells. (a) Dose-dependent effect of TAT-Bcpl $(1-20 \mu \mathrm{M})$ on the $\mathrm{H}_{2} \mathrm{O}_{2}$ content in $\mathrm{H} 9 \mathrm{c} 2$ cells grown under physiological conditions. (b) Effect of the TAT-Bcpl pretreatment on unstressed and $\mathrm{H}_{2} \mathrm{O}_{2}$-stressed cells. Unstressed cells (dark bars); $\mathrm{H}_{2} \mathrm{O}_{2}$-stressed cells (light bars).

were or were not subjected to oxidative stress to establish the effect of TAT-Bcpl on the $\mathrm{H}_{2} \mathrm{O}_{2}$ content in $\mathrm{H} 9 \mathrm{c} 2$ cells.

In the first case, the $\mathrm{H}_{2} \mathrm{O}_{2}$ levels in $\mathrm{H} 9 \mathrm{c} 2$ cell lysates were determined after incubation with increasing amounts ( 1 to $20 \mu \mathrm{M}$ ) of TAT-Bcpl for $1 \mathrm{~h}$ at $37^{\circ} \mathrm{C}$. The $\mathrm{H}_{2} \mathrm{O}_{2}$ levels in the lysates were determined using the Fluorescent Peroxide Sensor (see Section 2.7). As shown in Figure 6(a), a decrease of $\mathrm{H}_{2} \mathrm{O}_{2}$ content was detected in a TAT-Bcpl dose-dependent manner, indicating that the protein was able to cooperate with the endogenous reducing systems for $\mathrm{H}_{2} \mathrm{O}_{2}$ removal.

In the latter case, we investigated the antioxidant activity of TAT-Bcp1 by measuring the $\mathrm{H}_{2} \mathrm{O}_{2}$ levels in cells subjected to oxidative stress. As shown in Figure 6(b), the $\mathrm{H}_{2} \mathrm{O}_{2}$ levels in the TAT-Bcpl pretreated, stressed cells (see methods) were significantly reduced compared to the untreated samples. Taken together, these results indicate that TAT-Bcpl reduces the $\mathrm{H}_{2} \mathrm{O}_{2}$ content in $\mathrm{H} 9 \mathrm{c} 2$ cells under both physiological and oxidative stress conditions.

3.7. TAT-Bcp1 Protects $\mathrm{H} 9 \mathrm{c} 2$ Cardiomyoblasts from $\mathrm{H}_{2} \mathrm{O}_{2}$ Induced Cell Apoptosis. The $\mathrm{H} 9 \mathrm{c} 2$ cells were pretreated with 


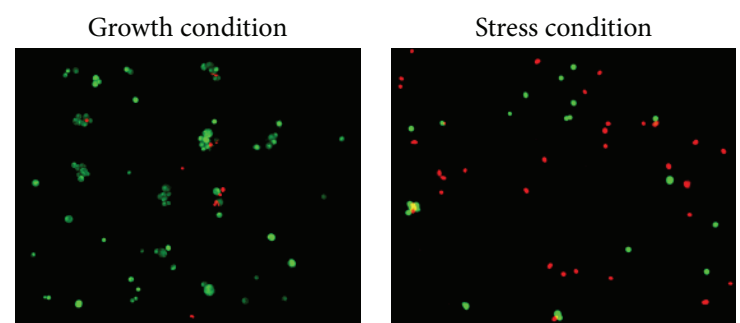

(a)

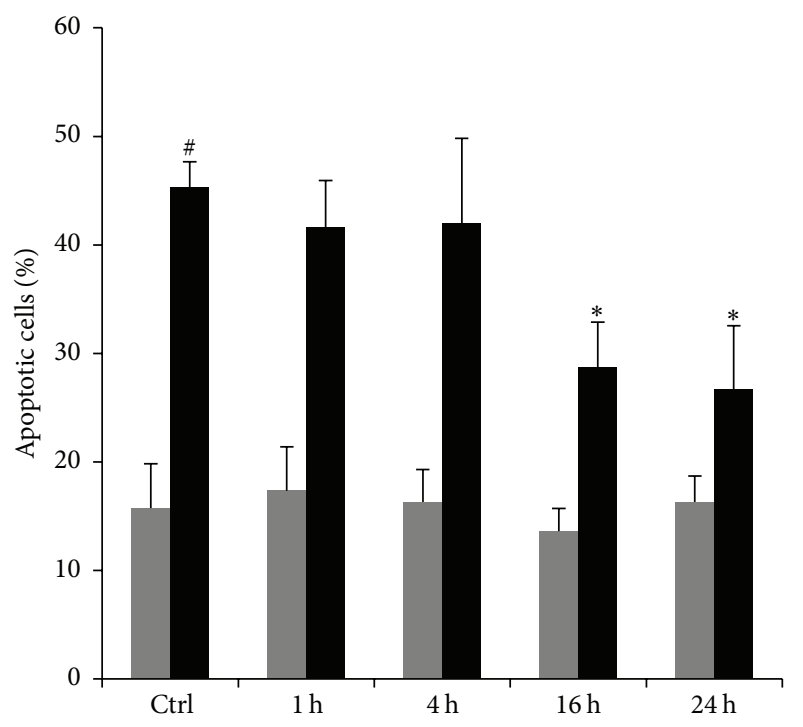

(b)

Figure 7: Effect of TAT-Bcp1 on cell apoptosis. Cell apoptosis was evaluated using $\mathrm{EB}$ and $\mathrm{AO}$ staining. $\mathrm{H} 9 \mathrm{c} 2$ cells were treated with TAT-Bcp1 $(10 \mu \mathrm{M})$ for different times $(1 \mathrm{~h}, 4 \mathrm{~h}, 16 \mathrm{~h}$, and $24 \mathrm{~h}$ ) and then subjected to oxidative stress with $0.3 \mathrm{mM} \mathrm{H}_{2} \mathrm{O}_{2}$ for $1 \mathrm{~h}$. (a) Representative images of the control cells (untreated with TAT-Bcp1) under growth and stress conditions showing both apoptotic (red) and live (green) cells. (b) The graph shows the mean percentages \pm SD. of apoptotic cells. The grey and black bars represent the unstressed and stressed cells, respectively. ${ }^{\#} p \ll 0.01$ versus the Ctrl growth condition; ${ }^{*} p \ll 0.001$ versus the Ctrl stress condition.

$10 \mu \mathrm{M}$ TAT-Bcpl for different incubation times (1-24h) and then exposed to $0.3 \mathrm{mM} \mathrm{H} \mathrm{O}_{2}$ for $1 \mathrm{~h}$ to study the effect of TAT-Bcpl on $\mathrm{H}_{2} \mathrm{O}_{2}$-induced apoptosis. Cell apoptosis was analysed by EB and $\mathrm{AO}$ staining (Figure $7(\mathrm{a})$ ).

A significant increase in the number of apoptotic cells was observed following the induction of oxidative stress; the percentage of $\mathrm{H}_{2} \mathrm{O}_{2}$-treated apoptotic cells was approximately 3 -fold higher $(45.3 \pm 2.3 \%)$ (Figure $7(\mathrm{~b})$, Ctrl black bar) than the unstressed cells $(15.7 \pm 4.1 \%)$ (Figure 7 (b), Ctrl grey bar). Pretreatment with TAT-Bcpl produced a protective effect against $\mathrm{H}_{2} \mathrm{O}_{2}$-induced cell apoptosis in a time-dependent manner. Indeed, after $1 \mathrm{~h}$ and $4 \mathrm{~h}$ incubation with TAT-Bcpl, the percentage of apoptotic cells was $41.6 \pm$ $4.3 \%$ and $42 \pm 7,8 \%$, respectively, similar to that observed under stress conditions. In contrast, at $16 \mathrm{~h}$ and $24 \mathrm{~h}$, the percentage of apoptotic cells was significantly reduced 1.6fold $(28.7 \pm 4.2 \%$ and $26.6 \pm 5.9 \%$, resp.). Furthermore,

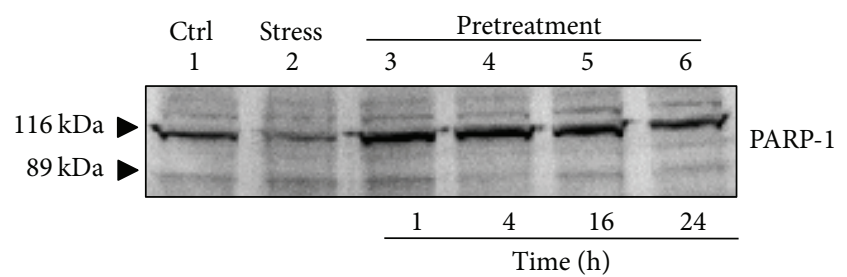

(a)

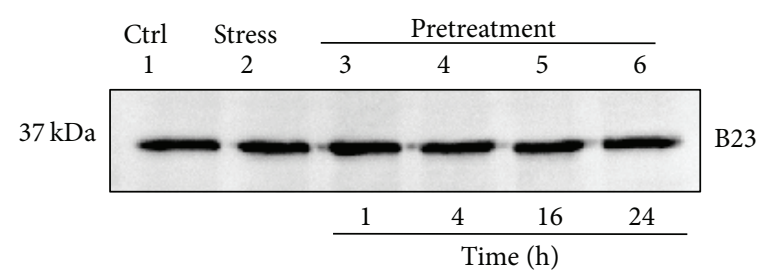

(b)

FIGURE 8: PARP-1 cleavage analysis. A western blot analysis of PARP-1 was performed using nuclear extracts. H9c2 cells were cultured under growth (lane 1) and stress conditions with $0.3 \mathrm{mM}$ $\mathrm{H}_{2} \mathrm{O}_{2}$ for $3 \mathrm{~h}$ (lane 2) or pretreated with TAT-Bcpl $(10 \mu \mathrm{M})$ for different times, $1 \mathrm{~h}$ (lane 3), $4 \mathrm{~h}$ (lane 4), $16 \mathrm{~h}$ (lane 5), and $24 \mathrm{~h}$ (lane 6), before oxidative stress was induced (a). B23 was used as the nuclear marker (b). Both the $116 \mathrm{kDa}$ full-length fragment and $89 \mathrm{kDa}$ cleaved fragment are shown.

the administration of TAT-Bcp1 to the unstressed cells did not induce any increase in cell apoptosis (Figure 7(b), grey bars), consistent with the results obtained from the MTT assay.

PARP-1 cleavage was examined by a western blot analysis of nuclear extracts to confirm the effect of TAT-Bcpl on $\mathrm{H}_{2} \mathrm{O}_{2}$-induced cell apoptosis (Figure 8). Typical PARP-1 cleavage was detected under the stress conditions induced by incubating the cells with $0.3 \mathrm{mM} \mathrm{H}_{2} \mathrm{O}_{2}$ for $3 \mathrm{~h}$ (Figure 8, lane 2), whereas pretreatment with $10 \mu \mathrm{M}$ TAT-Bcpl inhibited PARP-1 cleavage, showing a pattern that was similar to the control (Figure 8, lanes 3-6). In particular, under stress conditions, the level of the full-length fragment showed a $25 \%$ decrease compared to the control, whereas, after the TAT$\mathrm{Bcp} 1$ pretreatment, the level of the full-length fragment level was $94 \%$ after $1 \mathrm{~h}$ and $100 \%$ after 4,16 , and $24 \mathrm{~h}$, showing a cellular response that was comparable among the different pretreatment times.

In accord with the data from the EB and AO assays, the PARP-1 cleavage analysis confirms the antiapoptotic effect of TAT-Bcpl in $\mathrm{H}_{2} \mathrm{O}_{2}$-stressed cells.

\section{Discussion}

Prxs have recently received more attention because they are very efficient at removing low concentrations of $\mathrm{H}_{2} \mathrm{O}_{2}$ due to both their high abundance and low $K_{m}(\sim 20 \mu \mathrm{M})$ [28, 29]. Prxs, which are usually expressed in different isoforms, are evolutionarily conserved from the Archaea, such as $S$. solfataricus, in which four enzymes have been extensively characterized, to man, in which six isoenzymes with different 
roles and subcellular localizations have been identified. The ubiquity of Prxs and their homology conserved among the different phylogenetic domains show the important roles of these enzymes in addition to their peroxidase activities [30]. Although they retained the Trx fold that characterizes this family and peroxidase activity [2], these enzymes have implemented their functions by inserting a sensitivity motif in their structure to achieve fine tuning of the peroxide levels and play a regulatory role in cells. Growing evidence suggests both the unquestionable involvement of Prxs in the oxidative stress response and their role in regulating the intracellular $\mathrm{H}_{2} \mathrm{O}_{2}$ levels, which are responsible for cell proliferation, angiogenesis, and apoptosis [31-33]. Furthermore, it was shown that the sensitivity motif that promotes the overoxidation of Prx evolved independently in eukaryotic and prokaryotic species [34].

Our studies have focused on the antioxidant activity of a robust Prx to develop new antioxidant drugs; we chose prokaryotic Prx, Bcpl, from S. solfataricus that lacks the sensitivity motif and has a higher robustness compared to its eukaryotic counterparts. Starting from these differences, we first assessed whether Bcpl exhibited peroxidase activity under conditions that are typical of mammalian cells and in the presence of the eukaryotic recycling system yTrxR/yTrx. Our results showed that the enzyme can function at $37^{\circ} \mathrm{C}$ and $\mathrm{pH} 7.0$ and is still stable after $16 \mathrm{~h}$ incubation under these conditions, highlighting the potential use of this enzyme in biotechnological applications [35]. In contrast to eukaryotic and bacterial Prxs, Bcpl has a peculiar recycling system composed of TrxR/PDO [13] instead of the TrxR/Trx reducing system that is generally used by eukaryotes. Consequently, it was not obvious whether Bcpl could interact with $y \operatorname{Trx}$ in the hybrid regenerating system. Our results not only showed that Bcpl was effective at reducing the $\mathrm{H}_{2} \mathrm{O}_{2}$ levels in the presence of the $y \operatorname{TrxR} / y \operatorname{Trx}$ system but also showed that its affinity with $y \operatorname{Trx}$ was comparable to that reported for human Prxs [18], suggesting a possible activity of Bcpl in eukaryotic cells. Based on the in vitro characterization, we analysed the effect of $\mathrm{Bcpl}$ on $\mathrm{H}_{2} \mathrm{O}_{2}$-induced apoptosis into $\mathrm{H} 9 \mathrm{c} 2$ cells, with the aim of analysing the possible use of the archaeal Prx as an antioxidant.

We designed the fusion protein TAT-Bcpl to mediate its internalization into $\mathrm{H} 9 \mathrm{c} 2$ cells and to analyse the effect of $\mathrm{Bcpl}$ on the cell stress response. TAT-Bcpl was effectively detected in the cells at $1 \mathrm{~h}$ after administration and gradually decreased to $70 \%$ after $24 \mathrm{~h}$, in agreement with the protein turnover rates. Furthermore, the protein did not induce any cytotoxic effects, but it could have a cytoprotective effect, as shown by the slight but significant increase in cell viability at $16 \mathrm{~h}$ and $24 \mathrm{~h}$. The results obtained in this study indicate that TAT-Bcpl not only efficiently decreased the $\mathrm{H}_{2} \mathrm{O}_{2}$ levels in $\mathrm{H} 9 \mathrm{c} 2$ cells under both physiological and stressed conditions, showing that the enzyme can use the endogenous recycling system, but was also able to reduce apoptosis, as shown in the EB/AO staining assay in Figure 7 and in the PARP-1 cleavage analysis in Figure 8. Together, these results suggest that the antioxidant activity of TAT-Bcpl could play a role in protecting cells from apoptosis.

\section{Conclusions}

This study is the first report of an archaeal enzyme delivered into mammalian cultured cells that is able to protect cells from oxidative stress by reducing both the peroxide levels inside the cells and the resulting apoptosis. The intrinsic stability of Bcpl and its modification, which provides the ability to penetrate cells, makes TAT-Bcpl a good candidate to study the effectiveness of scavenging ROS in the cell. Growing evidence is highlighting the roles of Prxs in different diseases, ranging from diabetes to neurological disorders to cardiovascular diseases; therefore, this work aims to provide new insights into the possibility of using alternative sources of antioxidant enzymes, such as those from thermophilic microorganisms.

\section{Competing Interests}

The authors declare that there is no conflict of interests regarding the publication of this paper.

\section{Acknowledgments}

The authors thank Dr. Sang Won Kang, Center for Cell Signaling Research and Division of Molecular Life Sciences, Ewha Woman's University, Seoul, Korea, for generously providing the plasmids: pET17yTrx and pET17yTrxR. The work was supported by grants from POR Campania FSE 2007/2013, Progetto CARINA CUP B25B09000080007, and Sostegno Territoriale alle Attività di Ricerca (STAR) 2014, University of Naples Federico II, CUP E68C13000020003.

\section{References}

[1] M. Mittal, M. R. Siddiqui, K. Tran, S. P. Reddy, and A. B. Malik, "Reactive oxygen species in inflammation and tissue injury," Antioxidants and Redox Signaling, vol. 20, no. 7, pp. 1126-1167, 2014.

[2] E. Pedone, D. Limauro, K. D’Ambrosio, G. De Simone, and S. Bartolucci, "Multiple catalytically active thioredoxin folds: a winning strategy for many functions," Cellular and Molecular Life Sciences, vol. 67, no. 22, pp. 3797-3814, 2010.

[3] A. Hall, P. A. Karplus, and L. B. Poole, "Typical 2-Cys peroxiredoxins-structures, mechanisms and functions," FEBS Journal, vol. 276, no. 9, pp. 2469-2477, 2009.

[4] K. D’Ambrosio, D. Limauro, E. Pedone et al., "Insights into the catalytic mechanism of the Bcp family: functional and structural analysis of Bcpl from Sulfolobus solfataricus," Proteins: Structure, Function and Bioinformatics, vol. 76, no. 4, pp. 9951006, 2009.

[5] J. Lu and A. Holmgren, "The thioredoxin antioxidant system," Free Radical Biology and Medicine, vol. 66, pp. 75-87, 2014.

[6] Z. A. Wood, L. B. Poole, and P. A. Karplus, "Peroxiredoxin evolution and the regulation of hydrogen peroxide signaling," Science, vol. 300, no. 5619, pp. 650-653, 2003.

[7] C. Kumsta and U. Jakob, "Redox-regulated chaperones," Biochemistry, vol. 48, no. 22, pp. 4666-4676, 2009.

[8] D. G. Arias, A. Reinoso, N. Sasoni, M. D. Hartman, A. A. Iglesias, and S. A. Guerrero, "Kinetic and structural characterization of a typical two-cysteine peroxiredoxin from Leptospira 
interrogans exhibiting redox sensitivity," Free Radical Biology and Medicine, vol. 77, pp. 30-40, 2014.

[9] Y.-J. Bang, M. H. Oh, and S. H. Choi, "Distinct characteristics of two 2-cys peroxiredoxins of Vibrio vulnificus suggesting differential roles in detoxifying oxidative stress," The Journal of Biological Chemistry, vol. 287, no. 51, pp. 42516-42524, 2012.

[10] J. Park, S. Lee, S. Lee, and S. W. Kang, "2-Cys peroxiredoxins: emerging hubs determining redox dependency of Mammalian signaling networks," International Journal of Cell Biology, vol. 2014, Article ID 715867, 10 pages, 2014.

[11] D. Limauro, K. D’Ambrosio, E. Langella et al., "Exploring the catalytic mechanism of the first dimeric Bcp: functional, structural and docking analyses of Bcp4 from Sulfolobus solfataricus," Biochimie, vol. 92, no. 10, pp. 1435-1444, 2010.

[12] D. Limauro, E. Pedone, I. Galdi, and S. Bartolucci, "Peroxiredoxins as cellular guardians in Sulfolobus solfataricus: characterization of Bcp1, Bcp3 and Bcp4," FEBS Journal, vol. 275, no. 9, pp. 2067-2077, 2008.

[13] D. Limauro, E. Pedone, L. Pirone, and S. Bartolucci, "Identification and characterization of 1-Cys peroxiredoxin from Sulfolobus solfataricus and its involvement in the response to oxidative stress," The FEBS Journal, vol. 273, no. 4, pp. 721-731, 2006.

[14] D. Limauro, M. Saviano, I. Galdi, M. Rossi, S. Bartolucci, and E. Pedone, "Sulfolobus solfataricus protein disulphide oxidoreductase: Insight into the roles of its redox sites," Protein Engineering, Design and Selection, vol. 22, no. 1, pp. 19-26, 2009.

[15] E. Pedone, D. Limauro, and S. Bartolucci, "The machinery for oxidative protein folding in thermophiles," Antioxidants and Redox Signaling, vol. 10, no. 1, pp. 157-169, 2008.

[16] E. Pedone, G. Fiorentino, L. Pirone, P. Contursi, S. Bartolucci, and D. Limauro, "Functional and structural characterization of protein disulfide oxidoreductase from Thermus thermophilus HB27," Extremophiles, vol. 18, no. 4, pp. 723-731, 2014.

[17] M. Becker-Hapak, S. S. McAllister, and S. F. Dowdy, "TATmediated protein transduction into mammalian cells," Methods, vol. 24, no. 3, pp. 247-256, 2001.

[18] J.-A. Kim, S. Park, K. Kim, S. G. Rhee, and S. W. Kang, "Activity assay of mammalian 2-cys peroxiredoxins using yeast thioredoxin reductase system," Analytical Biochemistry, vol. 338, no. 2, pp. 216-236, 2005.

[19] D. Limauro, G. De Simone, L. Pirone, S. Bartolucci, K. D'Ambrosio, and E. Pedone, "Sulfolobus solfataricus thiol redox puzzle: characterization of an atypical protein disulfide oxidoreductase," Extremophiles, vol. 18, no. 2, pp. 219-228, 2014.

[20] I. Del Giudice, D. Limauro, E. Pedone, S. Bartolucci, and G. Fiorentino, "A novel arsenate reductase from the bacterium Thermus thermophilus HB27: its role in arsenic detoxification," Biochimica et Biophysica Acta-Proteins and Proteomics, vol. 1834, no. 10, pp. 2071-2079, 2013.

[21] M. Bradford, "A rapid and sensitive method for the quantitation of microgram quantities of protein utilizing the principle of protein-dye binding," Analytical Biochemistry, vol. 72, no. 1-2, pp. 248-254, 1976.

[22] T. Mosmann, "Rapid colorimetric assay for cellular growth and survival: application to proliferation and cytotoxicity assays," Journal of Immunological Methods, vol. 65, no. 1-2, pp. 55-63, 1983.

[23] S. Kasibhatla, G. P. Amarante-Mendes, D. Finucane, T. Brunner, E. Bossy-Wetzel, and D. R. Green, "Acridine Orange/Ethidium Bromide (AO/EB) staining to detect apoptosis," CSH Protocols, vol. 2006, no. 3, 2006.
[24] W. Lee, K.-S. Choi, J. Riddell et al., "Human peroxiredoxin 1 and 2 are not duplicate proteins: the unique presence of Cys 83 in Prxl underscores the structural and functional differences between Prx1 and Prx2," The Journal of Biological Chemistry, vol. 282, no. 30, pp. 22011-22022, 2007.

[25] S. G. Park, M.-K. Cha, W. Jeong, and I.-H. Kim, "Distinct physiological functions of thiol peroxidase isoenzymes in Saccharomyces cerevisiae," Journal of Biological Chemistry, vol. 275, no. 8, pp. 5723-5732, 2000.

[26] M. Valko, D. Leibfritz, J. Moncol, M. T. D. Cronin, M. Mazur, and J. Telser, "Free radicals and antioxidants in normal physiological functions and human disease," The International Journal of Biochemistry \& Cell Biology, vol. 39, no. 1, pp. 44-84, 2007.

[27] S. J. Watkins, G. M. Borthwick, and H. M. Arthur, "The H9C2 cell line and primary neonatal cardiomyocyte cells show similar hypertrophic responses in vitro," In Vitro Cellular \& Developmental Biology-Animal, vol. 47, no. 2, pp. 125-131, 2011.

[28] S. G. Rhee, "Overview on peroxiredoxin," Molecules and Cells, vol. 39, no. 1, pp. 1-5, 2016.

[29] E. Kubo, D. P. Singh, N. Fatma, and Y. Akagi, “TAT-mediated peroxiredoxin 5 and 6 protein transduction protects against high-glucose-induced cytotoxicity in retinal pericytes," Life Sciences, vol. 84, no. 23-24, pp. 857-864, 2009.

[30] A. Perkins, L. B. Poole, and P. A. Karplus, "Tuning of peroxiredoxin catalysis for various physiological roles," Biochemistry, vol. 53, no. 49, pp. 7693-7705, 2014.

[31] J. Kisucka, A. K. Chauhan, I. S. Patten et al., "Peroxiredoxin1 prevents excessive endothelial activation and early atherosclerosis," Circulation Research, vol. 103, no. 6, pp. 598-605, 2008.

[32] X. Guo, S. Yamada, A. Tanimoto et al., "Overexpression of peroxiredoxin 4 attenuates atherosclerosis in apolipoprotein $\mathrm{E}$ knockout mice," Antioxidants \& Redox Signaling, vol. 17, no. 10, pp. 1362-1375, 2012.

[33] J.-G. Park, J.-Y. Yoo, S.-J. Jeong et al., "Peroxiredoxin 2 deficiency exacerbates atherosclerosis in apolipoprotein E-deficient mice," Circulation Research, vol. 109, no. 7, pp. 739-749, 2011.

[34] A. J. Wadley, S. Aldred, and S. J. Coles, "An unexplored role for Peroxiredoxin in exercise-induced redox signalling?" Redox Biology, vol. 8, pp. 51-58, 2016.

[35] K. Egorova and G. Antranikian, "Industrial relevance of thermophilic Archaea," Current Opinion in Microbiology, vol. 8, no. 6, pp. 649-655, 2005. 

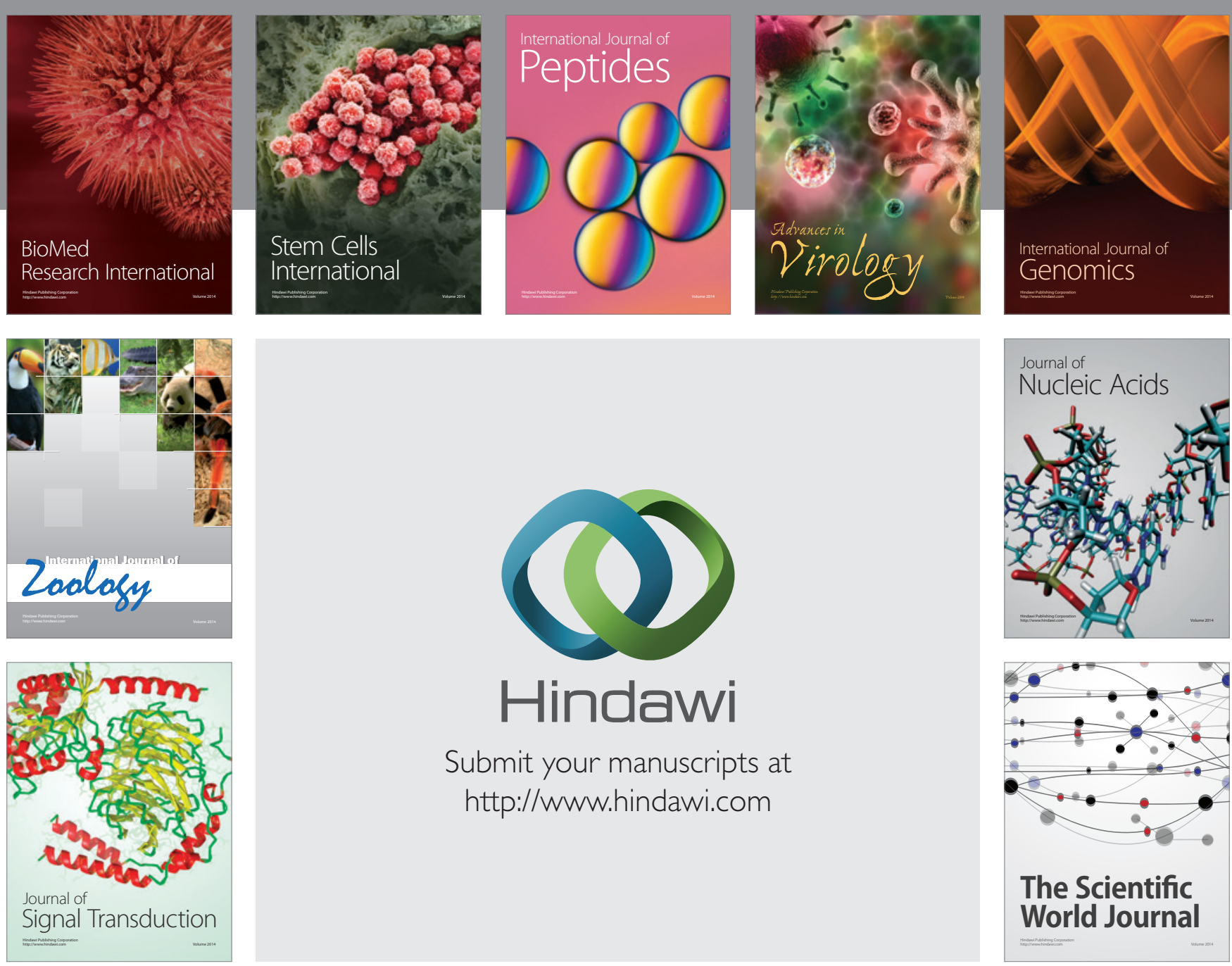

Submit your manuscripts at

http://www.hindawi.com
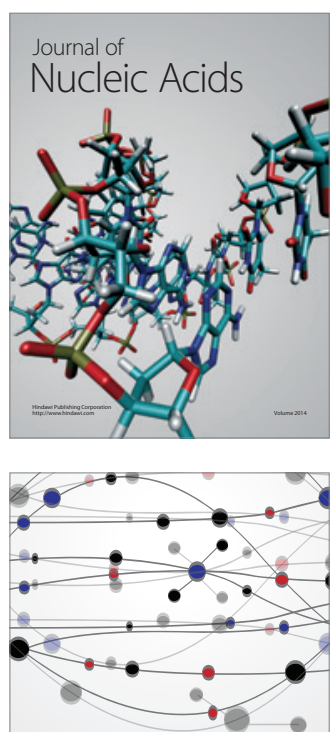

The Scientific World Journal
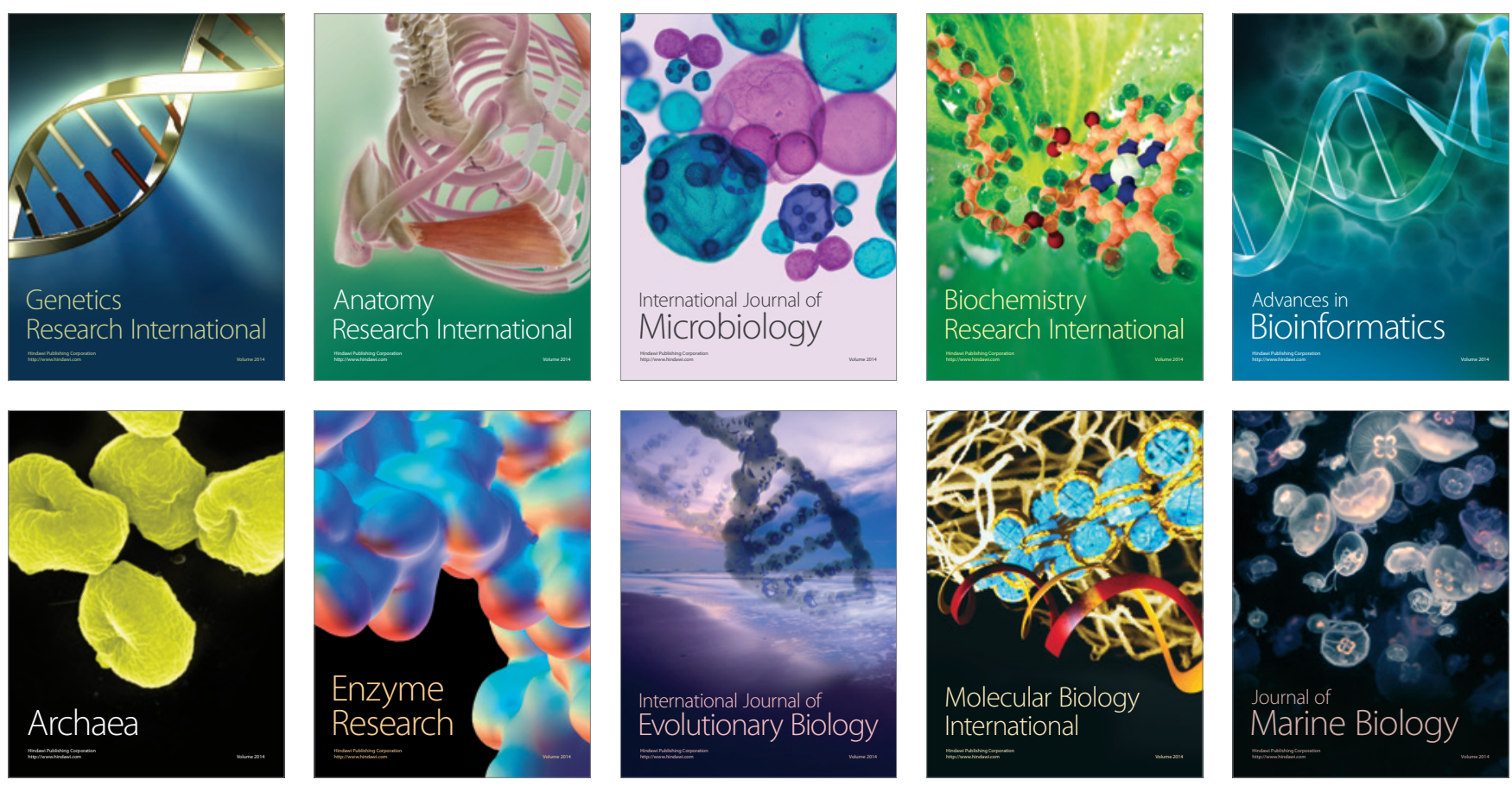